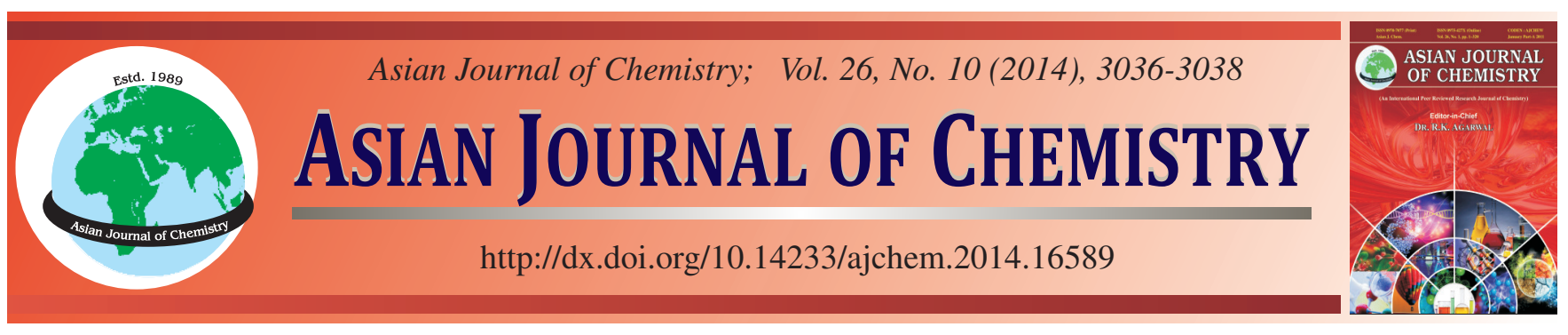

\title{
Solvothermal Synthesis and Crystal Structure of Cobalt(II) Complex Derived from 4-Heterocyclic Acylpyrazolone
}

\author{
Y.J. DING ${ }^{1, *}$ and C.X. ZHAO ${ }^{2}$
}

${ }^{1}$ Institute of Medicinal Chemistry, College of Chemistry and Chemical Engineering, Zhoukou Normal University, Zhoukou, P.R. China ${ }^{2}$ College of Chemistry and Chemical Engineering, Zhoukou Normal University, Zhoukou 466001, Henan Province, P.R. China

*Corresponding author: Tel/Fax: +86 394 8178253; E-mail: yongjieding@163.com

\begin{abstract}
A novel 4-acylpyrazolones complex of coblat $\left[\mathrm{Co}(\mathrm{CPTP})_{2}\left(\mathrm{C}_{2} \mathrm{H}_{5} \mathrm{OH}\right)_{2}\right]\left(\mathrm{C}_{2} \mathrm{H}_{5} \mathrm{OH}\right)_{2}$ (HCPTP = 1-(4-chlorophenyl)-3-phenyl-4-thenoyl$1 \mathrm{H}$-pyrazol-5-ol) has been synthesized and characterized structurally. It crystallizes in the triclinic space group P-1 with a = 11.8582 (8), $\mathrm{b}=14.2225(9), \mathrm{c}=14.5396$ (9) $\AA ; \alpha=91.450(2), \beta=104.323(2), \gamma=91.395(2), \mathrm{V}=2374.0(3) \AA^{3}, \mathrm{C}_{14} \mathrm{H}_{20} \mathrm{~N}_{2} \mathrm{O}_{18} \mathrm{Co}_{3}, \mathrm{Mr}=1002.87$, $\mathrm{Z}=2, \mathrm{Dc}=1.403 \mathrm{~g} / \mathrm{cm}^{3}, \mathrm{~m}=0.619 \mathrm{~mm}^{-1}, \mathrm{~F}(000)=1042, \mathrm{R}=0.0411$ and $\mathrm{wR}=0.1119$ for 7780 observed reflections with $\mathrm{I}>2 \mathrm{~s}(\mathrm{I})$. The complex has a six-coordinated $\mathrm{Co}(\mathrm{II})$ center in a distorted octahedral configuration with two ethanol ligands in cis position. These octahedral units are connected through hydrogen bonds via two ethanol molecules along the c-axis.
\end{abstract}

Keywords: Acylpyrazolone complex, Cobalt, Crystal structure.

\section{INTRODUCTION}

Acylpyrazolones are an interesting class of $\beta$-diketones compounds which exhibit keto-enol tautomerism ${ }^{1}$, which have been used as advantageous metal extractants and chelating reagents in the spectroscopic determination of metals in traces, due to quite a number of valuable properties of these complexes such as high extracting ability, intense colour of the complex extracts and low-solubility of the complexes in some solvents ${ }^{2,3}$. Moreover, their metal complexes have been found to display catalytic performance ${ }^{4,5}$, biological activity and enhanced luminescence ${ }^{6}$. HCPTP (1-(4-chlorophenyl)-3-phenyl-4thenoyl-1H-pyrazol-5-ol) is a new 4-heterocyclic acylpyrazolones (Scheme-I). In our previous work, the syntheses and crystal structures of HCPTP have been reported ${ }^{7}$.

The solvothermal synthesis has rapidly developed over the past several years due to its effectiveness, simplicity and environmental friendliness ${ }^{8,9}$. So, in this paper, as a continuation of our research, we report synthese by solvothermal method in a special mixed solvent system and crystal structure of complex about HCPTP containing $\mathrm{Co}(\mathrm{II})$ : $\left[\mathrm{Co}(\mathrm{CPTP})_{2}\left(\mathrm{C}_{2} \mathrm{H}_{5} \mathrm{OH}\right)_{2}\right]$ $\left(\mathrm{C}_{2} \mathrm{H}_{5} \mathrm{OH}\right)_{2}$.

\section{EXPERIMENTAL}

All reagents used in the syntheses were analytical grade and used without further purification. Elemental analyses for carbon, hydrogen and nitrogen were performed on an
Elementar vario EL III elemental analyzer. The infrared spectra (4000-600 $\mathrm{cm}^{-1}$ ) were recorded by using $\mathrm{KBr}$ pellet on a Nicolet 5700 spectrophotometer. Thermal analysis was performed on a Netzsch STA449F3 TG-DSC thermal analyzer with a heating rate of $5 \mathrm{~K} / \mathrm{min}$. UV/visible spectra were recorded on a Perkin-Elmer Lambda35 spectrophotometer.

\section{Synthesis of $\left[\mathrm{Co}(\mathrm{CPTP})_{2}\left(\mathrm{C}_{2} \mathrm{H}_{5} \mathrm{OH}\right)_{2}\right]\left(\mathrm{C}_{2} \mathrm{H}_{5} \mathrm{OH}\right)_{2}$}

Synthesis of the Co(II) complex (Scheme-II): A solution of $\mathrm{CoCl}_{2}(1 \mathrm{mmol}, 0.1300 \mathrm{~g})$ in $5 \mathrm{~mL}$ diethyl ether was added to a solution of HCPTP ( $2 \mathrm{mmol}, 0.7620 \mathrm{~g})$ in $10 \mathrm{~mL}$ anhydrous ethanol. The mixture was placed in a $30 \mathrm{~mL}$ Teflon-lined stainless steel vessel with addition of a few drops of glacial acetic acid as a catalyst, gradually heated to $120{ }^{\circ} \mathrm{C}$ for $48 \mathrm{~h}$ and then cooled to room temperature over $48 \mathrm{~h}$. Red block crystals suitable for X-ray analysis were obtained, yield: $85 \%$. The reaction procedure is shown in Scheme-II.

For $\mathbf{C}_{48} \mathbf{H}_{48} \mathbf{N}_{4} \mathbf{O}_{8} \mathbf{S}_{2} \mathbf{C o C l}_{2}$ : Anal. calcd (\%): C, 57.49; H, 4.82; N, 5.59. Found: C, 57.38; H, 4.94; N, 5.47. Infrared spectrum $\left(\mathrm{KBr}, \mathrm{v}_{\max }, \mathrm{cm}^{-1}\right)$ : 3421(w), 1604(s), 1568(s), 1471(s), 1234(w), 1178(w), 1093(w).

X-ray crystallography: Red single crystal of the complex $(0.41 \times 0.34 \times 0.25 \mathrm{~mm})$ was put on a Bruker SMART APEX II CCD diffractometer equipped with a graphite-monochromated $\operatorname{MoK}_{\alpha}$ radiation $(\lambda=0.71073 \AA)$ by using a $\phi / \omega$ scan technique at room temperature. 8794 independent reflections $\left(\mathrm{R}_{\mathrm{int}}=0.0228\right)$ in the range $1.43<\theta<25.50$ with $-14 \leq \mathrm{h} \leq 14$, 
<smiles>O=C(c1cccs1)c1c(-c2ccccc2)nn(-c2ccc(Cl)cc2)c1O</smiles>

(enol-form) Scheme-I: Enol-form and keto-form of HCPTP

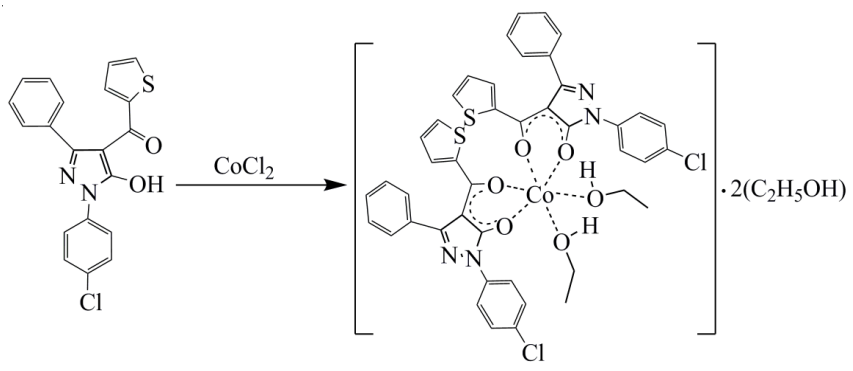

Scheme-II: Synthesis of $\left[\mathrm{Co}(\mathrm{CPTP})_{2}\left(\mathrm{C}_{2} \mathrm{H}_{5} \mathrm{OH}\right)_{2}\right]\left(\mathrm{C}_{2} \mathrm{H}_{5} \mathrm{OH}\right)_{2}$

$-17 \leq \mathrm{k} \leq 17,-16 \leq 1 \leq 17$ were collected at 296 (2) K. The structure was solved by direct methods with SHELXS- $97^{10}$. The hydrogen atoms were assigned with common isotropic displacement factors and included in the final refinement by use of geometrical restrains, while the non-hydrogen atoms were treated with common anisotropic displacement factors and included in the final refinement with geometrical restrains. A full-matrix least-squares refinement on $\mathrm{F}^{2}$ was carried out using SHELXL-9 $7^{11}$. The final agreement factor values are $\mathrm{R}$ $=0.0411$ and $\mathrm{wR}=0.1119$. Crystallographic data and refinement parameters are listed in Table-1. CCDC 909347 contains

\begin{tabular}{|c|c|}
\hline \multicolumn{2}{|c|}{$\begin{array}{c}\text { TABLE-1 } \\
\text { CRYSTALLOGRAPHIC DATA FOR } \\
{\left[\mathrm{Co}(\mathrm{CPTP})_{2}\left(\mathrm{C}_{2} \mathrm{H}_{5} \mathrm{OH}\right)_{2}\right]\left(\mathrm{C}_{2} \mathrm{H}_{5} \mathrm{OH}\right)_{2}}\end{array}$} \\
\hline Compound & {$\left[\mathrm{Co}(\mathrm{CPTP})_{2}\left(\mathrm{C}_{2} \mathrm{H}_{5} \mathrm{OH}\right)_{2}\right]\left(\mathrm{C}_{2} \mathrm{H}_{5} \mathrm{OH}\right)_{2}$} \\
\hline Color/shape & Red/block \\
\hline Formula & $\mathrm{C}_{48} \mathrm{H}_{48} \mathrm{~N}_{4} \mathrm{O}_{8} \mathrm{~S}_{2} \mathrm{CoCl}_{2}$ \\
\hline Formula weight & 1002.87 \\
\hline Temperature (K) & $296(2)$ \\
\hline Wavelength $(\AA)$ & 0.71073 \\
\hline Crystal system & Triclinic \\
\hline Space group & $\mathrm{P}-1$ \\
\hline Unit cell dimensions & $\begin{array}{l}\mathrm{a}=11.8582(8) \AA, b=14.2225(9) \\
\AA, \mathrm{c}=14.5396(9) \AA, \alpha=91.450 \\
(2), \beta=104.323(2), \gamma=91.395(2)\end{array}$ \\
\hline Z Volume, $\AA^{3}$ & $22374.0(3)$ \\
\hline Calculated density $\left(\mathrm{mg} / \mathrm{m}^{3}\right)$ & 1.403 \\
\hline Absorption coefficient $\left(\mathrm{mm}^{-1}\right)$ & 0.619 \\
\hline $\mathrm{F}(000)$ & 1042 \\
\hline$\theta$ range for data collection $\left({ }^{\circ}\right)$ & $1.43-25.50$ \\
\hline Reflections collected & 28612 \\
\hline Independent reflection & $8794[\mathrm{R}($ int $)=0.0228]$ \\
\hline Refinement method & Full-matrix least-squares on $\mathrm{F}^{2}$ \\
\hline Data / restraints / parameters & $8794 / 3 / 606$ \\
\hline Goodness-of-fit on $\mathrm{F}^{2}$ & 1.049 \\
\hline Final $R$ indices $[I>2 \sigma(I)]$ & $\mathrm{R} 1=0.0411, \mathrm{wR} 2=0.1119$ \\
\hline $\mathrm{R}$ indices (all data) & $\mathrm{R} 1=0.0471, \mathrm{wR} 2=0.1193$ \\
\hline Largest diff. peak and hole & 1.191 and $-0.447 \mathrm{e} / \AA^{3}$ \\
\hline
\end{tabular}

the supplementary crystallographic data for this paper. These data can be obtained free of charge from the Cambridge Crystallographic Data Centre via www.ccdc.cam.ac.uk/ data_request/cif.

\section{RESULTS AND DISCUSSION}

The structure of the Co(II) complex is shown in Fig. 1. The $\mathrm{X}$-ray analysis revealed that the complex was a 6-coordinate mononuclear $\mathrm{Co}$ (II) complex with the metal coordinated by two oxygens of ethanol and four oxygens of two bidentate pyrazolonate ligands $\mathrm{CPTP}^{-}$. $\mathrm{Co}(\mathrm{II})$ is located in the center of the octahedral.

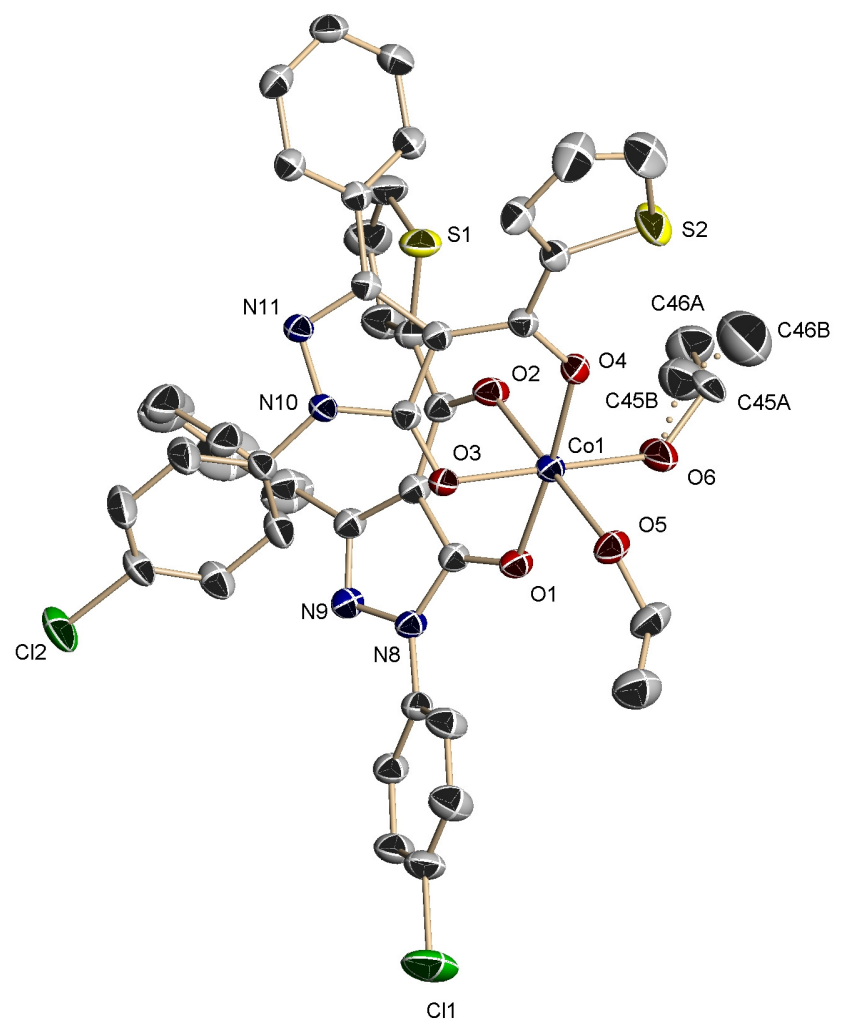

Fig. 1. Molecular structure of $\left[\mathrm{Co}(\mathrm{CPTP})_{2}\left(\mathrm{C}_{2} \mathrm{H}_{5} \mathrm{OH}\right)_{2}\right]\left(\mathrm{C}_{2} \mathrm{H}_{5} \mathrm{OH}\right)_{2}$ in the solid state. (30\% probability ellipsoids. The two uncoordinated ethanol molecule are omitted for clarity)

The $\mathrm{O}(1)-\mathrm{Co}(1)-\mathrm{O}(4)$ angle is $175.35(6)^{\circ}$, while the angles of $\mathrm{O}(2)-\mathrm{Co}(1)-\mathrm{O}(3), \mathrm{O}(3)-\mathrm{Co}(1)-\mathrm{O}(5), \mathrm{O}(5)-\mathrm{Co}(1)-\mathrm{O}(6)$ and $\mathrm{O}(6)-\mathrm{Co}(1)-\mathrm{O}(2)$ are $90.53(6)^{\circ}, 90.49(7)^{\circ}, 88.47(8)^{\circ}$ and $90.52(7)^{\circ}$, respectively, add up to $360.01(36)^{\circ}$ (Table-2). So the coordination around the Co is a slightly distorted octahedron. The two ethanol molecules are mutually cis, while the two bidentate HCPTP ligands adopt the deprotonated enol form, chelating to the $\mathrm{Co}$ atom via their $\mathrm{O}$ atoms. The cisconfiguration probably is allowed by the intermolecular hydrogen bonds, which afford greater stability than transconfiguration. The $\mathrm{C}$ atoms (C45A, C45B and C46A, C46B) of one of the two ethanol molecules coordinated to the Co atom are disordered over two sets in ratio 0.474(5):0.526(5).

The complex $\left[\mathrm{Co}(\mathrm{CPTP})_{2}\left(\mathrm{C}_{2} \mathrm{H}_{5} \mathrm{OH}\right)_{2}\right]\left(\mathrm{C}_{2} \mathrm{H}_{5} \mathrm{OH}\right)_{2}$ contains two co-crystallized uncoordinated alcohol molecules, which are linked vis hydrogen bonds bonding to the coordinated ethanol molecules (atoms $\mathrm{O}_{5}$ and $\mathrm{O}_{6}$; Table-3 and Fig. 2). The later, 
TABLE-2

SELECTED BOND LENGTHS ( $(\AA)$, ANGLES (DEG), AND DIHEDRAL ANGLES (DEG) FOR [CO(CPTP $\left.)_{2}\left(\mathrm{C}_{2} \mathrm{H}_{5} \mathrm{OH}\right)_{2}\right]$ $\left(\mathrm{C}_{2} \mathrm{H}_{5} \mathrm{OH}\right)_{2}$ WITH ESTIMATED STANDARD DEVIATIONS IN PARENTHESES

\begin{tabular}{lclc}
\hline \multicolumn{1}{c}{ Bond } & \multicolumn{1}{c}{$\mathrm{d}, \AA$} & \multicolumn{1}{c}{ Bond } & \multicolumn{1}{c}{$\mathrm{A}$} \\
\hline $\mathrm{Co}(1)-\mathrm{O}(1)$ & $2.0334(15)$ & $\mathrm{O}(1)-\mathrm{C}(7)$ & $1.265(3)$ \\
$\mathrm{Co}(1)-\mathrm{O}(2)$ & $2.0695(16)$ & $\mathrm{O}(3)-\mathrm{C}(29)$ & $1.277(3)$ \\
$\mathrm{Co}(1)-\mathrm{O}(4)$ & $2.0724(15)$ & $\mathrm{O}(2)-\mathrm{C}(16)$ & $1.260(3)$ \\
$\mathrm{Co}(1)-\mathrm{O}(3)$ & $2.0759(15)$ & $\mathrm{O}(4)-\mathrm{C}(36)$ & $1.257(3)$ \\
$\mathrm{Co}(1)-\mathrm{O}(6)$ & $2.0808(18)$ & $\mathrm{C}(28)-\mathrm{C}(29)$ & $1.418(3)$ \\
$\mathrm{Co}(1)-\mathrm{O}(5)$ & $2.1024(17)$ & $\mathrm{C}(7)-\mathrm{C}(8)$ & $1.427(3)$ \\
$\mathrm{C}(8)-\mathrm{C}(16)$ & $1.426(3)$ & $\mathrm{C}(28)-\mathrm{C}(36)$ & $1.432(3)$ \\
\hline \multicolumn{1}{c}{$\mathrm{Angle}$} & $\omega, \mathrm{deg}$ & $\mathrm{Angle}$ & $\omega, \mathrm{deg}$ \\
\hline $\mathrm{O}(1)-\mathrm{Co}(1)-\mathrm{O}(2)$ & $88.12(6)$ & $\mathrm{O}(6)-\mathrm{Co}(1)-\mathrm{O}(5)$ & $88.47(8)$ \\
$\mathrm{O}(2)-\mathrm{Co}(1)-\mathrm{O}(4)$ & $89.65(6)$ & $\mathrm{O}(1)-\mathrm{Co}(1)-\mathrm{O}(5)$ & $90.84(6)$ \\
$\mathrm{O}(4)-\mathrm{Co}(1)-\mathrm{O}(3)$ & $86.80(6)$ & $\mathrm{O}(4)-\mathrm{Co}(1)-\mathrm{O}(5)$ & $91.45(6)$ \\
$\mathrm{O}(1)-\mathrm{Co}(1)-\mathrm{O}(3)$ & $89.14(6)$ & $\mathrm{O}(3)-\mathrm{Co}(1)-\mathrm{O}(5)$ & $90.49(7)$ \\
$\mathrm{O}(1)-\mathrm{Co}(1)-\mathrm{O}(6)$ & $91.25(7)$ & $\mathrm{O}(2)-\mathrm{Co}(1)-\mathrm{O}(6)$ & $90.52(7)$ \\
$\mathrm{O}(4)-\mathrm{Co}(1)-\mathrm{O}(6)$ & $92.85(7)$ & $\mathrm{O}(2)-\mathrm{Co}(1)-\mathrm{O}(3)$ & $90.53(6)$ \\
\hline
\end{tabular}

TABLE 3

\begin{tabular}{ccccc} 
TABLE 3 \\
HYDROGEN BOND INTERACTIONS \\
FOR [Co(CPTP $\left.)_{2}\left(\mathrm{C}_{2} \mathrm{H}_{5} \mathrm{OH}\right)_{2}\right]\left(\mathrm{C}_{2} \mathrm{H}_{5} \mathrm{OH}\right)_{2}$ \\
\hline $\mathrm{D}-\mathrm{H} \ldots \mathrm{A}$ & $\mathrm{d}(\mathrm{D}-\mathrm{H})$ & $\mathrm{d}(\mathrm{H} \ldots \mathrm{A})$ & $\mathrm{d}(\mathrm{D} \ldots \mathrm{A})$ & $\angle$ (DHA) \\
\hline $\mathrm{O}(5)-\mathrm{H}(5 \mathrm{~A}) \ldots \mathrm{O}(8) \# 1$ & 0.81 & 1.97 & $2.762(3)$ & 167 \\
$\mathrm{O}(6)-\mathrm{H}(6 \mathrm{~A}) \ldots \mathrm{O}(7) \# 2$ & 0.80 & 1.87 & $2.669(3)$ & 173 \\
$\mathrm{O}(7)-\mathrm{H}(7) \ldots \mathrm{N}(9) \# 3$ & 0.82 & 2.14 & $2.951(3)$ & 168 \\
$\mathrm{O}(8)-\mathrm{H}(8) \ldots \mathrm{O}(3) \# 3$ & 0.82 & 2.02 & $2.818(3)$ & 163 \\
\hline
\end{tabular}

Symmetry transformations used to generate equivalent atoms: \#1: $x, y-$ $1, \mathrm{z}-1 ; \# 2: \mathrm{x}, \mathrm{y}-1, \mathrm{z} ; \# 3:-\mathrm{x}+1,-\mathrm{y}+1,-\mathrm{z}+1$

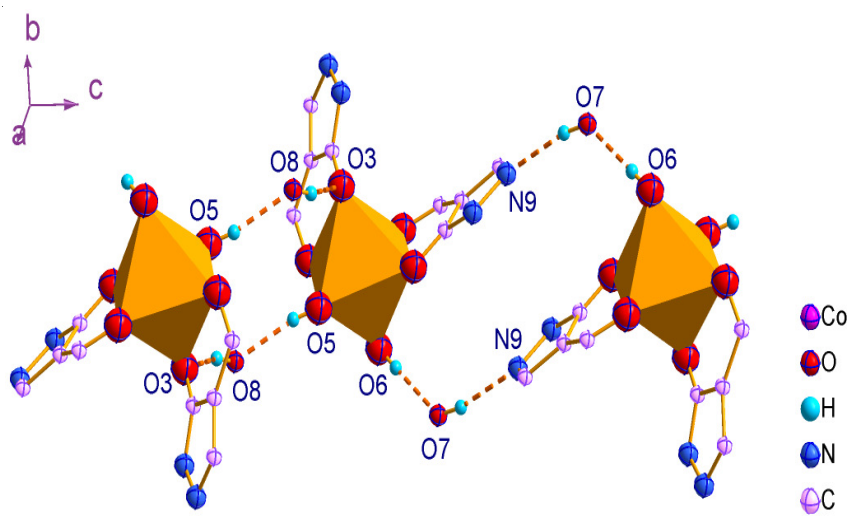

Fig. 2. View of the crystal structure of $\left[\mathrm{Co}(\mathrm{CPTP})_{2}\left(\mathrm{C}_{2} \mathrm{H}_{5} \mathrm{OH}\right)_{2}\right]\left(\mathrm{C}_{2} \mathrm{H}_{5} \mathrm{OH}\right)_{2}$. Some atoms were omitted for clarity

in turn, act as hydrogen bond donors to atoms $\mathrm{N}_{9}$ and $\mathrm{O}_{3}$ of neighboring complexes. Thus, the molecules form doublechains of hydrogen bonds along the $\mathrm{c}$ axis and a one-dimensional supramolecular structure is formed.

Thermal analysis: The DSC and TG analyses were carried out over the temperature range from 25 to $1200{ }^{\circ} \mathrm{C}$. The TGDSC curves of the $\left[\mathrm{Co}(\mathrm{CPTP})_{2}\left(\mathrm{C}_{2} \mathrm{H}_{5} \mathrm{OH}\right)_{2}\right]\left(\mathrm{C}_{2} \mathrm{H}_{5} \mathrm{OH}\right)_{2}$ shows decomposition of the complex in two regions (Fig. 3). The first region at about $35-175^{\circ} \mathrm{C}$ with a mass loss of $18.3 \%$ (calcd. $18.4 \%$ ) is due to the evolution of two solvate ethanol molecules and two ethanol molecules coordinated with Co. The second

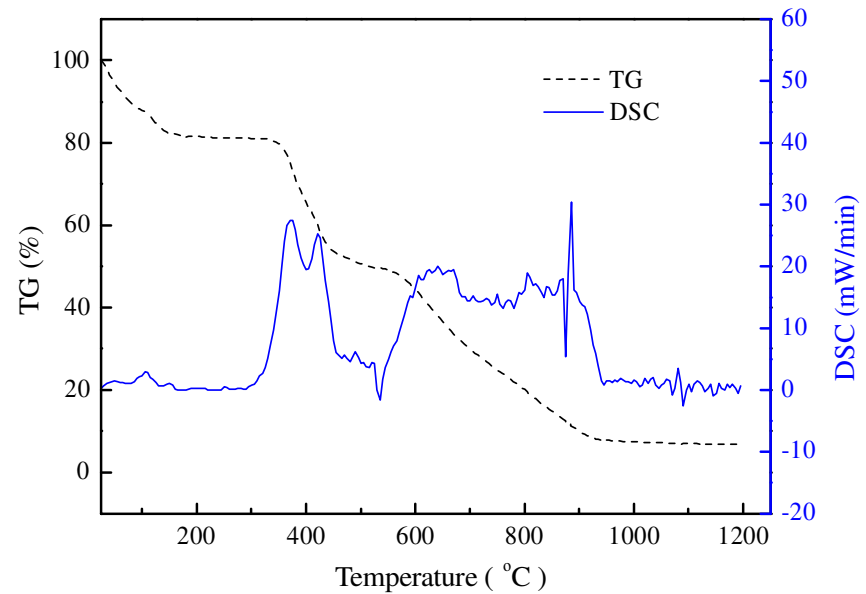

Fig. 3. TG-DSC curves of $\left[\mathrm{Co}(\mathrm{CPTP})_{2}\left(\mathrm{C}_{2} \mathrm{H}_{5} \mathrm{OH}\right)_{2}\right]\left(\mathrm{C}_{2} \mathrm{H}_{5} \mathrm{OH}\right)_{2}$

step occurs at $325-945^{\circ} \mathrm{C}$, accompanied by many exothermic peaks in the DSC curve due to the decomposition of the organic residues.

\section{Conclusion}

A new 4-heterocyclic acylpyrazolone cobalt (II) complex $\left[\mathrm{Co}(\mathrm{CPTP})_{2}\left(\mathrm{C}_{2} \mathrm{H}_{5} \mathrm{OH}\right)_{2}\right]\left(\mathrm{C}_{2} \mathrm{H}_{5} \mathrm{OH}\right)_{2}$, has been synthesized. The $\mathrm{Co}$ lies at an inversion center with a slightly distorted octahedral coordination environment. The intermolecular hydrogen bonds, $\mathrm{O}-\mathrm{H} \cdots \mathrm{O}$ and $\mathrm{O}-\mathrm{H} \cdots \mathrm{N}$ provide further stability.

\section{ACKNOWLEDGEMENTS}

The work was supported by the Henan Province Foundation and Advanced Technology Research Program (No. 122300410387), Scientific Research Starting Foundation for Doctor of Zhoukou Normal University (No. zksybscx201106), Innovation Fund project of Zhoukou Normal University (No. zksykycx201304) and the Scientific Research Foundation for Youth Teachers of Zhoukou Normal University (No. 2012QNB13).

\section{REFERENCES}

1. A. Cingolani, F. Marchetti, C. Pettinari, R. Pettinari, B.W. Skelton and A.H. White, Inorg. Chem. Commun., 7, 4387 (2004).

2. Y.A. Zolotov and N.M. Kuzmin, Extraction of Metals by Acylpyrazolones, Moscow: Nauka (1977).

3. S. Yamazaki, M. Hanada, Y. Yanase, C. Fukumori, K. Ogura, T. Saeki and S. Umetani, J. Chem. Soc. Perkin Trans. I, 693 (1999).

4. T. Yoshikuni, J. Mol. Catal. A, 148, 285 (1999).

5. T. Yoshikuni, J. Mol. Catal. A, 187, 143 (2002).

6. F. Marchetti, C. Pettinari and R. Pettinari, Coord. Chem. Rev., 249, 2909 (2005).

7. Y.J. Ding, C.X. Zhao, C.Y. Pei and G.X. Wen, Z. Naturforsch., 67b, 204 (2012).

8. X.M. Zhang, Coord. Chem. Rev., 249, 1201 (2005).

9. L. Xu, E. Wang, J. Peng and R. Huang, Inorg. Chem. Commun., 6, 740 (2003).

10. G.M. Sheldrick, SHELXS 97, Program for the Solution of Crystal Structures, University of Gottingen, Germany (1997).

11. G.M. Sheldrick, SHELXL 97, Program for the Refinement of Crystal Structures, University of Gottingen, Germany (1997). 